\title{
Caryopristimerin, the First Example of a Sesquiterpene-Triterpene Homo Diels-Alder Adduct, and a New 29-nor-Friedelane from Roots of Salacia crassifolia
}

\author{
Josana P. dos Santos, ${ }^{a, b}$ Bernardo L. Rodrigues, ${ }^{a}$ Willian X. C. Oliveira, ${ }^{\circledR a}$ \\ Fernando C. Silva, ${ }^{a}$ Grasiely F. de Sousa, ${ }^{\circledR a}$ Sidney A. Vieira Filho, ${ }^{c}$ \\ Lucienir P. Duarte ${ }^{\circledR *, a}$ and Roqueline R. Silva*,b \\ ${ }^{a}$ Departamento de Química, Universidade Federal de Minas Gerais, Av. Presidente Antônio Carlos, 6627, \\ Pampulha, 31270-901 Belo Horizonte-MG, Brazil \\ ${ }^{b}$ Departamento de Química, Universidade Federal dos Vales do Jequitinhonha e Mucuri, Campus JK, \\ Rodovia MGT 367, km 583, 5000, Alto da Jacuba, 39100-000 Diamantina-MG, Brazil \\ ${ }^{c}$ Escola de Farmácia, Universidade Federal de Ouro Preto, Campus Morro do Cruzeiro, s/n, \\ Bauxita, 35400-000 Ouro Preto-MG, Brazil
}

\begin{abstract}
Two new compounds, caryopristimerin and $2 \alpha, 3 \alpha, 22 \beta$-trihydroxy-21-oxo-29-nor-friedelan24-oic acid, were isolated from the hexane/ethyl ether extract of Salacia crassifolia roots. Caryopristimerin represents the first example of a homo Diels-Alder adduct of a sesquiterpene and a triterpene, and the new 29-nor-friedelane displays a highly oxygenated A ring with a carboxylic group at the unusual C-5 position. The new compounds were elucidated by infrared (IR), highresolution-atmospheric pressure chemical ionization-mass spectrometry (HR-APCI-MS), 1D/2D nuclear magnetic resonance (NMR) and single crystal X-ray diffraction analysis. Additionally, the known compounds 3-oxo-29-hydroxyfriedelane, pristimerin, tingenone and netzahualcoyonol are herein reported for the first time as constituents of S. crassifolia. Their structures were established by spectroscopic analysis.
\end{abstract}

Keywords: Salacia crassifolia, Celastraceae, homo Diels-Alder adduct, sesquiterpenetriterpene dimer

\section{Introduction}

The genus Salacia comprises more than 100 species and belongs to the Celastraceae family. ${ }^{1}$ It has been used in traditional medicine around many regions of the world, from South America to Asia., ${ }^{2,3}$ Phytochemical studies on Salacia species reported different bioactive secondary metabolites such as alkaloids, flavonoids, steroids and triterpenes. ${ }^{4-7}$ The isolated triterpenoids display a variety of skeletons like friedelane, ${ }^{6-8}$ ursane, oleanane and quinonemethide. ${ }^{6,8,9}$ The latter is only found in the roots and serves as a biomarker for the Celastraceae family. ${ }^{10,11}$

Salacia crassifolia (Mart. ex Schult.) G. Don is native from the Brazilian biome "Cerrado" and popularly known as "bacupari", "bacupari de caapuêra" and "saputá". Its leaves, stems, seeds and fruits are used in herbal medicine for the treatments of gastric ulcers, pediculosis capitis,

*e-mail: lucienir@ufmg.br; roquelinersm@yahoo.com.br common kidney disorders, chronic cough, headaches, malaria and skin cancer. ${ }^{12}$ The leaves were studied by Rodrigues et al. ${ }^{13}$ who isolated friedelanes, ursanes and oleananes, among other compounds. However, there are no further phytochemical studies of different parts of this plant. Therefore, this work aims to isolate and characterize compounds from roots of Salacia crassifolia.

The phytochemical study led to two novel and unusual compounds: a dimer named as caryopristimerin (1) and the $2 \alpha, 3 \alpha, 22 \beta$-trihydroxy-21-oxo-29-nor-friedelan24-oic acid (2). Quinonemethide dimers with aromatic moieties linked together by two ether bonds between the A rings via hetero Diels-Alder reaction are common in roots of the Celastraceae family. ${ }^{14}$ Diels-Alder adducts from quinonemethide and guaiane sesquiterpene with the same kind of linkages were also described for Cheiloclinium hippocratioides (Celastraceae).${ }^{15}$ However, this is the first time that a dimer between a quinonemethidederivative and the sesquiterpene caryophyllene (1) linked 
by carbon-carbon bonds via homo Diels-Alder reaction was isolated from this family. Also, compound 2 presents the uncommon skeleton 29-nor-friedelane with a highly oxidized A ring. The structures of both substances were confirmed by high-resolution-atmospheric pressure chemical ionization-mass spectrometry (HR-APCI-MS) and single crystal X-ray diffraction. In addition to these two new compounds, four known triterpenes were also isolated and identified as 3-oxo-29-hydroxyfriedelane (3), pristimerin (4), tingenone (5) and netzahualcoyonol (6) (Figure 1). All substances were characterized by Fourier transform infrared (FTIR) and 1D/2D nuclear magnetic resonance (NMR).

\section{Experimental}

\section{General experimental procedures}

Optical rotations were measured with an ADP220 Bellinghan + Stanley Ltd. polarimeter. FTIR spectra (ca. $1 \% \mathrm{KBr}$ solution) were obtained on a Shimadzu FTIR 408 spectrometer. The ${ }^{1} \mathrm{H}(400 \mathrm{MHz}, J$ in $\mathrm{Hz})$ and ${ }^{13} \mathrm{C}$ NMR $(100 \mathrm{MHz})$ spectra were recorded on a Bruker Avance DRX-400 spectrometer. Tetramethylsilane (TMS) or solvent signals of $\mathrm{CDCl}_{3}\left(\delta_{\mathrm{H}} 7.26 ; \delta_{\mathrm{C}} 77.00 \mathrm{ppm}\right)$ and dimethyl sulfoxide (DMSO- $d_{6}, \delta_{\mathrm{H}} 2.50 ; \delta_{\mathrm{C}} 39.51 \mathrm{ppm}$ ) were used as internal standards. HR-APCI-MS analyses were carried out on a Shimadzu LCMS-IT-TOF (liquid chromatography mass spectrometry-ion trap and time-of-flight) instrument in both positive and negative modes. Column chromatography (CC) and thin layer chromatographic (TLC) plates were carried out on silica gel 60 (70-230 Mesh, Merck) and silica gel
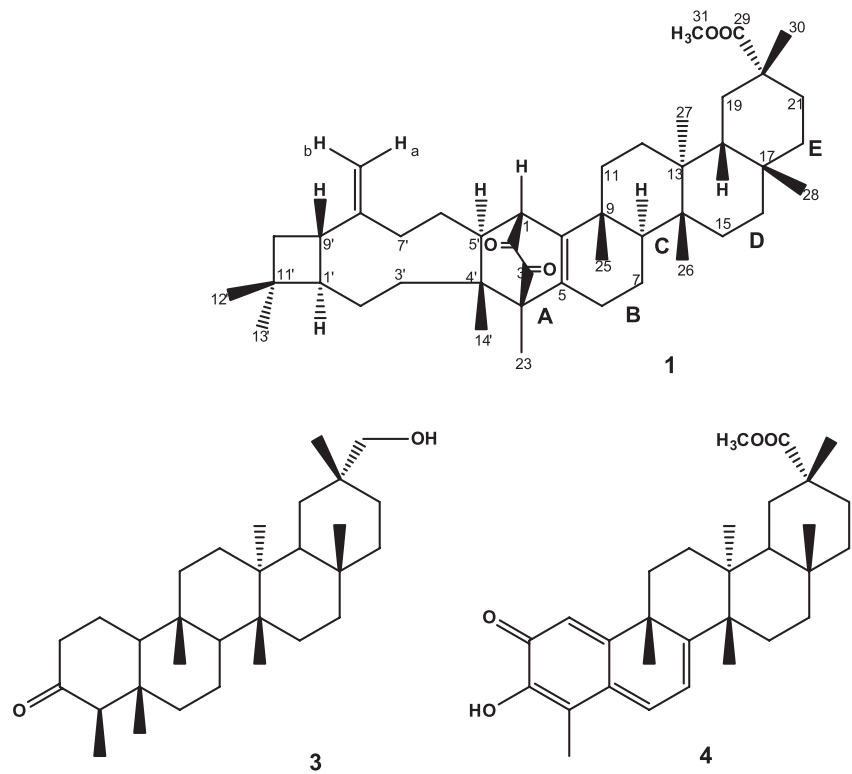

$60 \mathrm{G}$, respectively. Spots were visualized by heating after spraying with a solution of $1 \%$ ethanol-vanillin/3\% aqueous perchloric acid 1:1 v/v. Single crystal X-ray diffraction data were collected with an Oxford-Diffraction GEMINI-Ultra ( $293 \mathrm{~K}$ ) using Mo K $\alpha$ radiation $(0.71073 \AA$ A). Reduction data/analytical absorption corrections and space group identification were performed using CRYSALIS suite ${ }^{16}$ and XPREP, ${ }^{17}$ respectively. Structures were solved by direct methods with SIR- $92^{18}$ and refined by full-matrix least-squares against $\mathrm{F}^{2}$ with SHELX. ${ }^{17,18}$ Hydrogen atoms were assigned riding isotropic displacement parameters and constrained to idealized geometries. ${ }^{19}$ The theoretical crystal morphology and 3D chemical structures were established with Mercury ${ }^{\circledast .}{ }^{19}$

Plant material

Roots of Salacia crassifolia (Mart.) G. Don were collected in Montes Claros Municipality (16 $52^{\circ} 15^{\prime \prime} \mathrm{S}$, $44^{\circ} 00^{\prime} 58^{\prime \prime} \mathrm{W}$ ), avoiding more serious damages to the specimens, in December 2010. The plant was identified by Dr Maria Olívia Mercadante-Simões of Universidade de Montes Claros, Montes Claros, Minas Gerais State, Brazil. A voucher specimen (BHCB 144624) was deposited in the Herbarium of the Instituto de Ciências Biológicas of Universidade Federal de Minas Gerais, Belo Horizonte, Minas Gerais State, Brazil.

\section{Extraction and isolation}

The dried powdered roots of S. crassifolia $(607.0 \mathrm{~g})$ were extracted with hexane/ethyl ether $(1: 1 \mathrm{v} / \mathrm{v}, 3 \mathrm{~L})$ in a

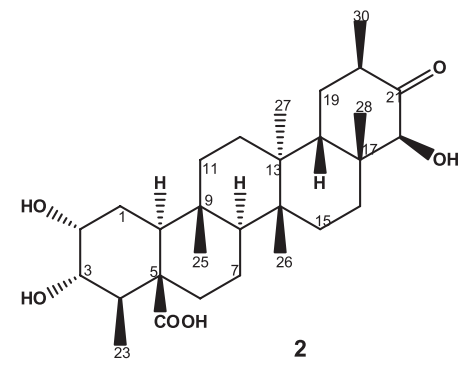

Figure 1. Compounds 1-6 from S. crassifolia roots.<smiles>CC1=C(C)c2ccc3c4c(ccc3c2=CC1=O)C(C)=C(O)C(=O)C=4</smiles> 
Soxhlet apparatus for $72 \mathrm{~h}$. Evaporation of the solvent under reduced pressure provided a dark extract $(27.0 \mathrm{~g})$. Part of this extract $(20.0 \mathrm{~g})$ was chromatographed on silica gel $60 \mathrm{CC}(3.5 \times 80 \mathrm{~cm})$, eluted with hexane, EtOAc and $\mathrm{MeOH}$ in mixtures of increasing polarity, yielding 101 fractions of $100 \mathrm{~mL}$ each. Fractions with similar TLC profile were combined and reduced to 7 groups (Gr-A-G). Gr-A (hexane) and Gr-B (hexane/EtOAc 8:2) afforded compound 1 $(31.5 \mathrm{mg})$ and compound $4(1.42 \mathrm{~g})$, respectively. Gr-C (hexane/EtOAc 6:4, $492.2 \mathrm{mg}$ ), Gr-D (hexane/EtOAc 6:4, $374.4 \mathrm{mg}$ ), Gr-E (hexane/EtOAc 1:1, $715.7 \mathrm{mg}$ ) and $\mathrm{Gr}-\mathrm{F}(\mathrm{MeOH}, 549.1 \mathrm{mg})$ were rechromatographed on silica gel $\mathrm{CC}$ using a gradient of hexane, EtOAc and $\mathrm{MeOH}$. Gr-C $(\mathrm{CC} 1.4 \times 83.5 \mathrm{~cm})$ provided compound 3 $(25.0 \mathrm{mg})$. Gr-D $(\mathrm{CC} 2.0 \times 60 \mathrm{~cm})$ furnished compound $\mathbf{5}$ $(11.0 \mathrm{mg})$. Gr-E $(\mathrm{CC} 1.4 \times 83.5 \mathrm{~cm})$ led to compound 4 (520.3 mg). Gr-F $(\mathrm{CC} 1.4 \times 83.5 \mathrm{~cm})$ furnished compound 6 $(170.0 \mathrm{mg})$. Finally, during the removal of solvent from Gr-G $(\mathrm{MeOH})$, a white solid precipitated and was filtered yielding compound $\mathbf{2}(19.0 \mathrm{mg}$ ). Compounds $\mathbf{1}$ and $\mathbf{2}$ were recrystallized from $\mathrm{EtOH}$.

\section{Caryopristimerin (1)}

Yellowish crystals; undergoes decomposition at $230{ }^{\circ} \mathrm{C} ; \alpha_{\mathrm{D}}^{23}-47.6\left(\mathrm{c} 0.011, \mathrm{CHCl}_{3}\right) ;$ FTIR $v_{\max } / \mathrm{cm}^{-1} 1728$, $1634,1458,1438,1196,1138,898,756 ;{ }^{1} \mathrm{H}(400 \mathrm{MHz}$, $\left.\mathrm{CDCl}_{3}\right)$ and ${ }^{13} \mathrm{C}$ NMR (100 MHz, $\left.\mathrm{CDCl}_{3}\right)$, see Table 1; HR-APCI-MS (positive-ion mode): $m / z$, calcd. for $\mathrm{C}_{45} \mathrm{H}_{67} \mathrm{O}_{4}$ $[\mathrm{M}+\mathrm{H}]^{+}$: 671.5039; found: 671.5005 .

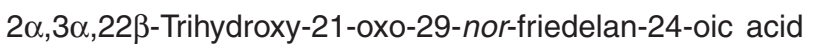
(2)

White crystals, undergoes decomposition at $271.5^{\circ} \mathrm{C}$; attempts to measure the optical rotation were unsuccessful due to the small amount obtained for this compound; FTIR $v_{\max } / \mathrm{cm}^{-1} 3556,3512,3408,1702,1458,1390,1204$, $752 ;{ }^{1} \mathrm{H}\left(400 \mathrm{MHz}\right.$, DMSO- $\left.d_{6}\right)$ and ${ }^{13} \mathrm{C}$ NMR $(100 \mathrm{MHz}$, DMSO- $d_{6}$ ), see Table 2; HR-APCI-MS (negative-ion mode): $m / z$, calcd. for $\mathrm{C}_{29} \mathrm{H}_{45} \mathrm{O}_{6}[\mathrm{M}-\mathrm{H}]^{-}: 489.3216$; found: 489.3292 .

\section{X-ray crystallographic analyses of compounds 1 and 2}

\section{Crystal data of compound 1}

$\mathrm{C}_{45} \mathrm{H}_{66} \mathrm{O}_{4}, \mathrm{M}$ (formula mass) $=670.96$, orthorhombic, space group $P 2{ }_{1} 2_{2}{ }_{1}, a=12.0810(5) \AA, b=14.0349(10) \AA$, $c=22.002(3) \AA, \mathrm{V}$ (unit cell volume) $=3730.5(6) \AA^{3}, \mathrm{Z}$ (No. of formula units per unit cell $)=4, \mathrm{~d}($ density $)=1.1 \mathrm{mg} \mathrm{cm}^{-3}$. The total number of measured independent reflections was 8467 , of which 6932 were observed with $\mathrm{F}^{2}>2 \sigma\left(\mathrm{F}^{2}\right)\left[\mathrm{F}^{2}\right.$ is observable intensity and $\sigma\left(\mathrm{F}^{2}\right)$ is the variance among observed intensities].
Final indices: $\mathrm{R}=0.0515$ and $\mathrm{wR}=0.1042, \mathrm{~S}=1.06$. $\left[\mathrm{R}=\Sigma|| \mathrm{F}_{\mathrm{o}}|-| \mathrm{F}_{\mathrm{c}} \| / \Sigma\left|\mathrm{F}_{\mathrm{o}}\right|\right.$, where $\mathrm{F}_{\mathrm{o}}$ is the observed structure factor and $F_{c}$ is the structure factor calculated from proposed model; $w \mathrm{R}=\left[\Sigma w\left(\left|\mathrm{~F}_{\mathrm{o}}\right|^{2}-\left|\mathrm{F}_{\mathrm{c}}\right|^{2}\right) 2 / \Sigma w\left|\mathrm{~F}_{\mathrm{o}}\right|^{1 / 2}\right]^{1 / 2}$, where $\mathrm{w}$ is a weighting factor defined as $w=\left[\sigma^{2}\left(\mathrm{~F}_{\mathrm{o}}{ }^{2}\right)+(\mathrm{a} P)^{2}+\mathrm{b} P\right]$ and $\mathrm{P}=\left[2 \mathrm{~F}_{\mathrm{c}}{ }^{2}+\operatorname{Max}\left(\mathrm{F}_{\mathrm{o}}^{2}, 0\right)\right] / 3 ; \mathrm{S}=\left\{\Sigma\left[w\left(\mathrm{~F}_{\mathrm{o}}{ }^{2}-\mathrm{F}_{\mathrm{c}}{ }^{2}\right)^{2} /(n-p)\right\}^{1 / 2}\right.$ with $n$ and $p$ the number of reflections and the total number of refined parameters.

\section{Crystal data of compound 2}

$\mathrm{C}_{29} \mathrm{H}_{46} \mathrm{O}_{6}, \mathrm{M}=490.33$, orthorhombic, space group $P 2{ }_{1}{ }_{1}{ }_{1}, a=11.3790(5) \AA, b=15.1209(5) \AA$, $c=29.0772(13) \AA, \mathrm{V}=5003.0(4) \AA^{3}, \mathrm{Z}=4, \mathrm{~d}=1.3 \mathrm{mg} \mathrm{cm}^{-3}$. The total number of measured independent reflections was 8467 , of which 6625 were observed $\left[\mathrm{F}^{2}>2 \sigma\left(\mathrm{F}^{2}\right)\right]$. Final indices: $\mathrm{R}=0.0676$ and $\mathrm{wR}=0.1383, \mathrm{~S}=0.99$.

\section{Results and Discussion}

Compound 1 was obtained as yellowish crystals. Its molecular formula $\mathrm{C}_{45} \mathrm{H}_{66} \mathrm{O}_{4}$ was determined by HR-APCI-MS and presented 13 degrees of unsaturation. In its IR spectrum, absorption bands for carbonyl groups and terminal methylidene group at 1728 and $898 \mathrm{~cm}^{-1}$ were observed, respectively. The ${ }^{1} \mathrm{H}$ NMR spectrum of $\mathbf{1}$ revealed the presence of ten methyl singlets, one of which was due to an $\mathrm{OCH}_{3}$ group $\left(\delta_{\mathrm{H}} 3.69 \mathrm{ppm}\right)$, and two singlets for a methylidene at $\delta_{\mathrm{H}} 4.88$ and $5.01 \mathrm{ppm}$. Analysis of the ${ }^{13} \mathrm{C}$ NMR data with the aid of distortionless enhancement by polarization transfer (DEPT)-135 experiments (Table 1) showed 45 carbon resonances (among them three $\mathrm{C}=\mathrm{O}$ and four olefinic carbon), suggesting a dimer composed by a triterpene and a sesquiterpene. This hypothesis was reinforced by the mass peaks at $m / z 467.3448\left[\mathrm{C}_{30} \mathrm{H}_{43} \mathrm{O}_{4}\right]^{+}$ (consistent with the molecular formula of a methoxylated quinonemethide) and at $m / z 205.0891\left[\mathrm{C}_{15} \mathrm{H}_{24}\right]^{+}$(consistent with a molecular formula of a sesquiterpene). In fact, the ${ }^{13} \mathrm{C}$ NMR data of caryophyllene oxide and $2 \alpha$-hydroxypopulnonic acid methyl ester were closely related to the sesquiterpene moiety and to the $\mathrm{C}, \mathrm{D}$ and $\mathrm{E}$ rings of compound $\mathbf{1}$, respectively. ${ }^{20,21}$

A detailed analysis was performed using 2D NMR (heteronuclear single quantum correlation (HSQC), heteronuclear multiple bond correlation (HMBC), correlation spectroscopy (COSY) and nuclear Overhauser effect (NOESY) spectra). In the HMBC spectrum, the olefinic protons $\mathrm{H}-15^{\prime}\left(\delta_{\mathrm{H}} 4.87\right.$ and $\left.\delta_{\mathrm{H}} 5.01 \mathrm{ppm}\right)$ correlated with C-9' $\left(\delta_{\mathrm{C}} 42.52 \mathrm{ppm}\right)$ and C-7' $\left(\delta_{\mathrm{C}} 36.12 \mathrm{ppm}\right)$. This last carbon correlated with $\mathrm{H}-5$ ' $\left(\delta_{\mathrm{H}} 1.54 / \delta_{\mathrm{C}} 44.39 \mathrm{ppm}\right)$. C-5' is one of the links of the dimer, due to its correlations with the triterpene (correlation with $\mathrm{H}-1\left(\delta_{\mathrm{H}} 3.23 \mathrm{ppm}\right)$ 
Table 1. ${ }^{1} \mathrm{H}$ and ${ }^{13} \mathrm{C}$ NMR (400 and $100 \mathrm{MHz}$, respectively, $\mathrm{CDCl}_{3}$ ) data assignments for compound $\mathbf{1}$

\begin{tabular}{|c|c|c|c|c|}
\hline No. & $\delta_{\mathrm{C}}$ & $\delta_{\mathrm{H}}{ }^{a}($ multiplicity, $J$ in $\mathrm{Hz}$ ) & $\begin{array}{c}\mathrm{HMBC} \\
(\mathrm{H} \rightarrow \mathrm{C}) \\
\end{array}$ & NOESY \\
\hline $1(\mathrm{CH})$ & 49.07 & 3.23 (bs) & $2,3,5,9,10,4^{\prime}, 5^{\prime}, 6^{\prime}$ & $25,5^{\prime}, 6^{\prime} \alpha, 7^{\prime} \alpha, 14^{\prime}$ \\
\hline $2(\mathrm{C})$ & 193.13 & & & \\
\hline $3(\mathrm{C})$ & 192.12 & & & \\
\hline $4(\mathrm{C})$ & 60.52 & & & \\
\hline $5(\mathrm{C})$ & 131.71 & & & \\
\hline $6\left(\mathrm{CH}_{2}\right)$ & 28.25 & $\begin{array}{l}2.01(\mathrm{~m}) \\
2.13(\mathrm{~m})\end{array}$ & $5,8,10$ & $\begin{array}{c}8,11 \beta, 23 \\
23\end{array}$ \\
\hline $7\left(\mathrm{CH}_{2}\right)$ & 18.31 & $\begin{array}{l}\text { (ß) } 1.37(\mathrm{~m}) \\
(\alpha) 1.67(\mathrm{~m})\end{array}$ & $5,6,9,14$ & $\begin{array}{c}7 \alpha, 26 \\
7 \beta\end{array}$ \\
\hline $8(\mathrm{CH})$ & 45.66 & $1.60(\mathrm{~m})$ & & 6 \\
\hline $9(\mathrm{C})$ & 37.43 & & & \\
\hline $10(\mathrm{C})$ & 148.80 & & & \\
\hline $11\left(\mathrm{CH}_{2}\right)$ & 30.96 & 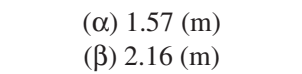 & 25 & $\begin{array}{c}12,27 \\
6\end{array}$ \\
\hline $12\left(\mathrm{CH}_{2}\right)$ & 29.69 & $1.34(\mathrm{~m})$ & & 11,25 \\
\hline $13(\mathrm{C})$ & 39.56 & & & \\
\hline $14(\mathrm{C})$ & 39.33 & & & \\
\hline $15\left(\mathrm{CH}_{2}\right)$ & 28.91 & $1.32(\mathrm{~m})$ & & \\
\hline $16\left(\mathrm{CH}_{2}\right)$ & 36.39 & $\begin{array}{l}\text { (ß) } 1.71(\mathrm{~m}) \\
(\alpha) 1.60(\mathrm{~m})\end{array}$ & & 26 \\
\hline $17(\mathrm{C})$ & 30.27 & & & \\
\hline $18(\mathrm{CH})$ & 44.53 & $1.54(\mathrm{~m})$ & 19,28 & $19 \beta$ \\
\hline $19\left(\mathrm{CH}_{2}\right)$ & 30.45 & $\begin{array}{l}\text { ( } \beta) 1.60(\mathrm{~m}) \\
(\alpha) 2.39(\mathrm{~m})\end{array}$ & 18,29 & 18,28 \\
\hline $20(\mathrm{C})$ & 40.66 & & & \\
\hline $21\left(\mathrm{CH}_{2}\right)$ & 29.98 & $0.98(\mathrm{~m})$ & 30 & $22 \alpha$ \\
\hline $22\left(\mathrm{CH}_{2}\right)$ & 36.70 & $\begin{array}{l}\text { ( } \beta) 1.01(\mathrm{~m}) \\
(\alpha) 2.04(\mathrm{~m})\end{array}$ & & 21,27 \\
\hline $23\left(\mathrm{CH}_{3}\right)$ & 9.05 & $1.15(\mathrm{~s})$ & $3,4,5,4$ & $6,11,6^{\prime}, 14^{\prime}$ \\
\hline $25\left(\mathrm{CH}_{3}\right)$ & 22.34 & $0.87(\mathrm{~s})$ & $9,10,11$ & 1,12 \\
\hline $26\left(\mathrm{CH}_{3}\right)$ & 16.04 & $0.84(\mathrm{~s})$ & 8,15 & $16 \beta$ \\
\hline $27\left(\mathrm{CH}_{3}\right)$ & 17.20 & $0.82(\mathrm{~s})$ & 18 & $11 \alpha, 19 \alpha, 22 \alpha, 31,13^{\prime}, 15^{\prime} \mathrm{a}, 15^{\prime} \mathrm{b}$ \\
\hline $28\left(\mathrm{CH}_{3}\right)$ & 31.86 & $1.09(\mathrm{~s})$ & 18 & $19 \beta$ \\
\hline $29(\mathrm{C})$ & 179.17 & & & \\
\hline $30\left(\mathrm{CH}_{3}\right)$ & 31.91 & $1.20(\mathrm{~s})$ & $19,20,29$ & 31 \\
\hline $31\left(\mathrm{O}-\mathrm{CH}_{3}\right)$ & 51.59 & $3.69(\mathrm{~s})$ & 29 & $27,30,13^{\prime}, 15^{\prime} \mathrm{b}$ \\
\hline $1^{\prime}(\mathrm{CH})$ & 60.81 & $1.25(\mathrm{~m})$ & $9^{\prime}, 11^{\prime}, 12^{\prime}$ & $13^{\prime}, 15^{\prime} \mathrm{b}$ \\
\hline $2^{\prime}\left(\mathrm{CH}_{2}\right)$ & 24.45 & $\begin{array}{l}1.41(\mathrm{~m}) \\
1.60(\mathrm{~m})\end{array}$ & 1', $3^{\prime}$ & $\begin{array}{l}9^{\prime}, 12^{\prime}, 14^{\prime} \\
6^{\prime} \alpha, 10^{\prime}\end{array}$ \\
\hline $3^{\prime}\left(\mathrm{CH}_{2}\right)$ & 41.29 & $0.98(\mathrm{~m})$ & & \\
\hline $1.60(\mathrm{~m})$ & 1 ' & & & \\
\hline $4^{\prime}(\mathrm{C})$ & 39.76 & & & \\
\hline $5^{\prime}(\mathrm{CH})$ & 44.39 & $1.54(\mathrm{~m})$ & $1,2,10,4^{\prime}, 7^{\prime}, 14^{\prime}$ & $1,15^{\prime} \mathrm{a}$ \\
\hline $6^{\prime}\left(\mathrm{CH}_{2}\right)$ & 25.09 & 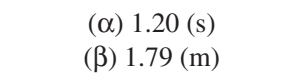 & 8 & $\begin{array}{c}1,2^{\prime}, 6^{\prime} \beta, 7^{\prime} \alpha \\
9^{\prime}, 14^{\prime}\end{array}$ \\
\hline $7^{\prime}\left(\mathrm{CH}_{2}\right)$ & 36.12 & 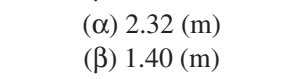 & 5 & $1,6^{\prime} \alpha, 15^{\prime} \mathrm{a}$ \\
\hline $8^{\prime}(\mathrm{C})$ & 151.40 & & & \\
\hline $9^{\prime}(\mathrm{CH})$ & 42.52 & $2.43(\mathrm{~m})$ & $1^{\prime}, 2^{\prime}, 8^{\prime}, 10^{\prime}, 15^{\prime}$ & $2^{\prime}, 6^{\prime} \beta, 10^{\prime}, 12^{\prime}$ \\
\hline $10^{\prime}\left(\mathrm{CH}_{2}\right)$ & 36.24 & $1.74(\mathrm{~m})$ & $8^{\prime}, 9^{\prime}, 11^{\prime}, 12^{\prime}, 13^{\prime}$ & $2^{\prime}, 9^{\prime}, 13^{\prime}, 15^{\prime} \mathrm{b}$ \\
\hline $11^{\prime}(\mathrm{C})$ & 34.79 & & & \\
\hline $12^{\prime}\left(\mathrm{CH}_{3}\right)$ & 21.94 & $0.99(\mathrm{~m})$ & $1^{\prime}, 13^{\prime}$ & 2', 9' \\
\hline $13^{\prime}\left(\mathrm{CH}_{3}\right)$ & 30.00 & $0.98(\mathrm{~m})$ & $10^{\prime}, 11^{\prime}, 12^{\prime}$ & $27,31,1^{\prime}, 10^{\prime}$ \\
\hline $14^{\prime}\left(\mathrm{CH}_{3}\right)$ & 16.70 & $0.73(\mathrm{~s})$ & $4,3^{\prime}, 4^{\prime}, 5^{\prime}$ & $1,23,2^{\prime}, 6^{\prime} \beta$ \\
\hline $15^{\prime}\left(\mathrm{CH}_{2}\right)$ & 111.77 & $\begin{array}{l}\text { (a) } 4.88(\mathrm{~s}) \\
\text { (b) } 5.01(\mathrm{~s})\end{array}$ & $7^{\prime}, 8^{\prime}, 9^{\prime}$ & $\begin{array}{l}27,31,5^{\prime}, 7^{\prime}, 15^{\prime} \mathrm{b} \\
7,31,1^{\prime}, 10^{\prime}, 15^{\prime} \mathrm{a}\end{array}$ \\
\hline
\end{tabular}

${ }^{a}$ Splitting multiplicities are reported as singlet (s), broad signal (bs) and multiplet (m). HMBC: heteronuclear multiple bond correlation; NOESY: nuclear Overhauser effect spectroscopy. 
and the sesquiterpene (correlation with $\mathrm{H}-14^{\prime}\left(\delta_{\mathrm{H}} 0.73\right.$ ppm)) moiety. Moreover, H-5' correlated with C-4' $\left(\delta_{\mathrm{C}} 39.76 \mathrm{ppm}\right)$, which is another link since this carbon correlated with the methyls $\mathrm{H}-14$ ' $\left(\delta_{\mathrm{H}} 0.73 \mathrm{ppm}\right)$ and $\mathrm{H}-23$ $\left(\delta_{\mathrm{H}} 1.15 \mathrm{ppm}\right)$. The methyl H-23 correlated with C-4 $\left(\delta_{\mathrm{C}}\right.$ $60.52 \mathrm{ppm})$ and a carbonyl group $\left(\delta_{\mathrm{C}} 192.12 \mathrm{ppm}(\mathrm{C}-3)\right)$. This carbonyl group correlated with $\mathrm{H}-1$, which also correlated with a second carbonyl group at $\delta_{\mathrm{C}} 193.13 \mathrm{ppm}$ (C-2), suggesting the existence of a bicyclic system with $\mathrm{C}-1 / \mathrm{C}-4$ in the bridgehead positions. $\mathrm{H}-1$ also correlated with C-5 $\left(\delta_{\mathrm{C}} 131.71 \mathrm{ppm}\right), \mathrm{C}-9\left(\delta_{\mathrm{C}} 37.43 \mathrm{ppm}\right)$, C-10 $\left(\delta_{\mathrm{C}} 148.80 \mathrm{ppm}\right), \mathrm{C}-4{ }^{\prime}\left(\delta_{\mathrm{C}} 39.76 \mathrm{ppm}\right)$ and C-6' $\left(\delta_{\mathrm{C}} 25.09 \mathrm{ppm}\right)$. The complete 2D NMR analysis showed an unusual sesquiterpene-triterpene dimer formed via homo Diels-Alder reaction. The literature ${ }^{15,22}$ reports this kind of dimer, together with quinonemethide-aromatic triterpenes, only via a hetero Diels-Alder reaction.

In the NOESY spectrum, the protons of methylene $\mathrm{H}-15$ ' were defined by the correlations $\mathrm{H}-15^{\prime} \mathrm{a}\left(\delta_{\mathrm{H}} 4.88 \mathrm{ppm}\right) / \mathrm{H}-7$ ' $\left(\delta_{\mathrm{H}} 2.32 \mathrm{ppm}\right)$ and $\mathrm{H}-15^{\prime} \mathrm{b}\left(\delta_{\mathrm{H}} 5.01 \mathrm{ppm}\right) / \mathrm{H}-10^{\prime}$ $\left(\delta_{\mathrm{H}} 1.74 \mathrm{ppm}\right)$. The NOE of the methyls $\mathrm{H}-31\left(\delta_{\mathrm{H}} 3.69 \mathrm{ppm}\right)$, belonging to the carboxymethyl group, and H-27 $\left(\delta_{\mathrm{H}} 0.82 \mathrm{ppm}\right)$ proofs these groups are oriented on the same side. Surprisingly, both H-15' (a and b) and H-13' correlated with $\mathrm{H}-31$ and $\mathrm{H}-27$, suggesting a folding of the molecule.

The crystal structure of $\mathbf{1}$ was unambiguously obtained from single crystal X-ray diffraction experiments. For data collection, a single crystal obtained from ethanol slow evaporation was submitted to a nitrogen flow at $150 \mathrm{~K}$ and irradiated with $\mathrm{Cu} \mathrm{K} \alpha$ radiation $(1.5418 \AA$ ). The compound crystallized in the non-centrosymmetric orthorhombic space group $P 2{ }_{1} 2_{1} 2_{1}$, which indicated the obtained crystals were enantiomerically pure. Figure 2 shows the representation of structure $\mathbf{1}$ demonstrating that the dimer is indeed composed by a triterpene and a sesquiterpene. Anomalous dispersion on single crystal data was insufficient to determine the absolute structure of $\mathbf{1}$. The triterpene conformations were determined for the rings as chair (C and E), semi-chair (B) and boat (A) (Figure 2, rings identification follows Figure 1). The torsion angles observed for $\mathrm{C}$ and $\mathrm{E}$ rings were greater than $50^{\circ}$ (standard for chair conformations) and close to zero for $\mathrm{B}$ ring $\left(5.5(1)^{\circ}\right.$, standard for semi-chair); however, D ring presented a torsion angle of $27.1(1)^{\circ}$, indicating a distorted conformation between chair and semi-chair. Furthermore, the carbon-carbon distances C-15'-C-31 = 5.200(5) $\AA$, $\mathrm{C}-15^{\prime}-\mathrm{C}-27=4.161(5) \AA, \mathrm{C}-27-\mathrm{C}-31=3.828(5) \AA$ and $\mathrm{C}-31-\mathrm{C}-13^{\prime}=3.832(5) \AA$ proof the folding of the molecule, previously suggested by the NOESY spectrum.

Mesa-Siverio et al..$^{15}$ also reported the isolation of sesquiterpene-triterpene dimers; however, they are connected

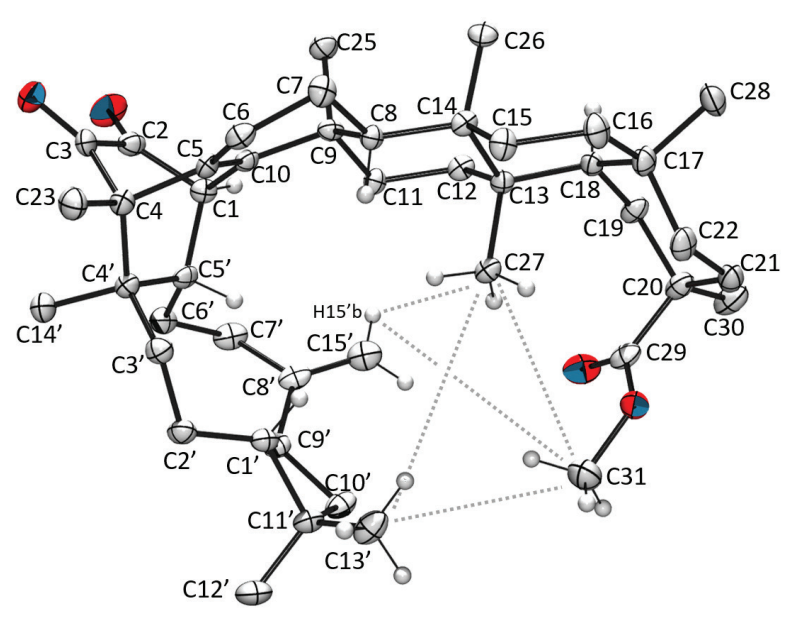

Figure 2. X-ray crystal structure of $\mathbf{1}$. Some hydrogen atoms were omitted for better $3 \mathrm{D}$ visualization. Dotted lines represent relevant interactions observed in the NOESY spectrum.

by two ether linkages. Therefore, caryopristimerin (1) represents the first example of a sesquiterpene-triterpene dimer linked by a carbon-carbon bond. Also, this is the first report of a caryophyllene-triterpene dimer. The dimerization process may occur by a homo Diels-Alder reaction, different from the hetero Diels-Alder reported for Celastraceae triterpene dimers. ${ }^{23}$ Scheme 1 shows a plausible biosynthetic pathway for caryopristimerin (1) in which a pristimerin derivative under keto-enol equilibrium reacts with caryophyllene.

In order to prove that compound $\mathbf{1}$ is in fact biosynthesized by the plant, and not an artifact formed during the extraction, two experiments were performed. The first experiment consisted in a chemical reaction between caryophyllene (commercial) and pristimerin (quinonemethide isolated in higher quantities and similar to the precursor of compound $\mathbf{1}$ ). Both compounds were submitted to similar conditions employed in the extraction methodology. The analysis of the reaction mixture by high-performance liquid chromatography-ultraviolet (HPLC-UV) and TLC plates after $72 \mathrm{~h}$ showed no changes in the starting materials, indicating that no artifact was formed during the extract preparation.

The second experiment consisted in preparing a new extract through maceration (room temperature, $72 \mathrm{~h}$ ) and isolating compound $\mathbf{1}$. However, due to the limited amounts of roots, only a small quantity of extract was obtained and analyzed by liquid chromatography-electrospray ionization-quadrupole time of flight-mass spectrometry (LC/ESI-QTOF/MS) in positive mode. The mass peak at $\mathrm{m} / \mathrm{z} 693.4860$ (calcd. 693.4853) was observed and attributed to $\mathrm{C}_{45} \mathrm{H}_{66} \mathrm{O}_{4} \mathrm{Na}^{+}[\mathrm{M}+\mathrm{Na}]^{+}$, coherent with compound $\mathbf{1}$ molecular formula, reinforcing the evidence that this dimer is biosynthesized by the plant. 


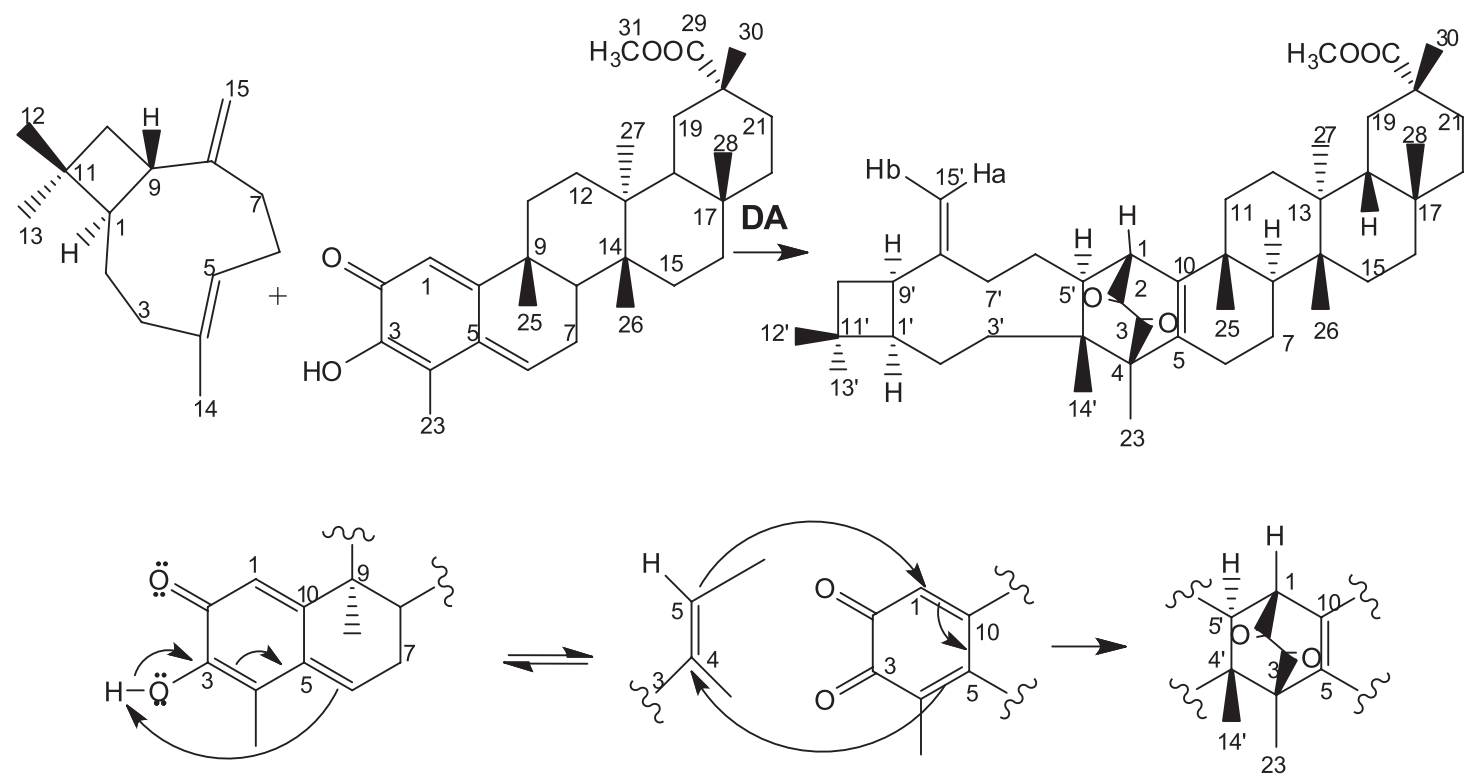

Scheme 1. Diels-Alder reaction and hypothetical pathway of $\mathbf{1}$.

Compound 2 was obtained as white crystals. Its molecular formula $\mathrm{C}_{29} \mathrm{H}_{46} \mathrm{O}_{6}$ was determined by HR-APCI-MS and presented seven unsaturation degrees. The IR spectrum showed absorption bands for carbonyl $\left(1702 \mathrm{~cm}^{-1}\right)$ and hydroxyls groups $\left(3556,3512\right.$ and $\left.3408 \mathrm{~cm}^{-1}\right)$. The ${ }^{1} \mathrm{H}$ NMR spectrum of $\mathbf{2}$ displayed six methyl groups, two of them as doublets $\left(\delta_{\mathrm{H}} 0.79\right.$ and $\left.0.90 \mathrm{ppm}\right)$, and three oxymethine protons $\left(\delta_{\mathrm{H}} 3.51,3.82\right.$ and $\left.4.41 \mathrm{ppm}\right)$, suggesting three hydroxyl groups. The ${ }^{13} \mathrm{C}$ NMR spectrum presented 29 signals, which, based on DEPT-135 experiment, were associated to 6 methyl groups, 8 methylenes, 8 methines, and 7 non-hydrogenated carbons (with one keto carbonyl carbon at $\delta_{\mathrm{C}} 213.22 \mathrm{ppm}$, and one carboxylic acid carbon at $\delta_{\mathrm{C}} 176.48 \mathrm{ppm}$ ). These data suggested that compound 2 is a nor-friedelane acid triterpene.

In the HMBC spectrum, the most shielded methyl doublet at $\delta_{\mathrm{H}} 0.79 \mathrm{ppm}(\mathrm{H}-23)$ correlated with the signal $\delta_{\mathrm{C}} 71.21 \mathrm{ppm}(\mathrm{C}-3)$, confirming that C-3 has a hydroxyl group. C-3 correlated with the signal at $\delta_{\mathrm{H}} 1.46 \mathrm{ppm}(\mathrm{H}-4)$, which correlated with the signal at $\delta_{\mathrm{C}} 176.48 \mathrm{ppm}(\mathrm{C}-24)$, attributing the carboxylic group in an unusual oxidation position at C-5. ${ }^{24}$ In the COSY spectrum, the carbinolic signal at $\delta_{\mathrm{H}} 3.82 \mathrm{ppm}$ correlated with $\mathrm{H}-3\left(\delta_{\mathrm{H}} 3.51 \mathrm{ppm}\right)$ and $\mathrm{H}-1\left(\delta_{\mathrm{H}} 1.59 \mathrm{ppm}\right)$, which correlated with $\mathrm{H}-10$ $\left(\delta_{\mathrm{H}} 1.72 \mathrm{ppm}\right)$, locating the second hydroxyl group at $\mathrm{C}-2$. The second methyl doublet at $\delta_{\mathrm{H}} 0.90 \mathrm{ppm}$ correlated with a $\mathrm{CH}_{2}\left(\delta_{\mathrm{C}} 30.91 \mathrm{ppm}\right), \mathrm{C}=\mathrm{O}\left(\delta_{\mathrm{C}} 213.22 \mathrm{ppm}\right)$ and a $\mathrm{CH}$ $\left(\delta_{\mathrm{C}} 40.81 \mathrm{ppm}\right)$. These correlations confirmed compound 2 as a 29-nor-friedelane, similar to triptocalline A. ${ }^{25}$ The complete chemical shift assignments of compound $\mathbf{2}$ (Table 2) were established by further detailed analysis of HSQC, HMBC and COSY spectra.
Similar to compound $\mathbf{1}$, a single crystal of compound $\mathbf{2}$ was obtained from ethanol and it crystallized in the noncentrosymmetric orthorhombic space group $P 2{ }_{1}{ }_{2}{ }_{1}{ }_{1}$. The crystal data was collected under nitrogen flow at $150 \mathrm{~K}$ using $\mathrm{Cu} \mathrm{K} \alpha$ radiation. The asymmetric unit of 2 shows two independent molecules with small differences in the conformation and torsions due to the hydrogen bond interactions. Anomalous dispersion effect on the single crystal data was insufficient to determine the absolute structure of $\mathbf{2}$. Analyzing one of the molecules of the asymmetric unit, compound $\mathbf{2}$ was identified as $2 \alpha, 3 \alpha, 22 \beta$-trihydroxy-21-oxo-29-nor-friedelan-24-oic acid with the uncommon 29-nor-friedelane skeleton with a highly oxygenated A ring. All the rings assumed a chair conformation with the exception of D ring, which presented a distorted chair with torsion angle $\left(29.7(2)^{\circ}\right)$ indicating an intermediate conformation between chair and semi-chair (Figure 3).

The other six known compounds were identified as 3-oxo-29-hydroxyfriedelane $(3),{ }^{26}$ pristimerin $(4),{ }^{27}$ tingenone ${ }^{28}(\mathbf{5})$ and netzahualcoyonol $(\mathbf{6})^{29}$ by comparison of their physical and spectroscopic data with those reported in the literature.

\section{Conclusions}

Four triterpenes, one nor-triterpene and one sesquiterpene-triterpene dimer were isolated from Salacia crassifolia roots. The 1D/2D NMR and single crystal X-ray diffraction data of caryopristimerin (1) and $2 \alpha, 3 \alpha, 22 \beta$-trihydroxy-21-oxo-29-nor-friedelan24-oic acid (2) are herein described for the first time. A 
Table 2. ${ }^{1} \mathrm{H}$ and ${ }^{13} \mathrm{C}$ NMR (400 and $100 \mathrm{MHz}$, respectively, DMSO- $d_{6}$ ) data assignments for compound 2

\begin{tabular}{|c|c|c|c|}
\hline No. & $\delta_{\mathrm{C}}$ & $\begin{array}{c}\delta_{\mathrm{H}}{ }^{\mathrm{a}}(\text { multiplicity } \\
J \text { in } \mathrm{Hz} \text { ) }\end{array}$ & $\mathrm{HMBC}(\mathrm{H} \rightarrow \mathrm{C})$ \\
\hline $1\left(\mathrm{CH}_{2}\right)$ & 26.65 & $1.59(\mathrm{~m}), 2.13(\mathrm{~m})$ & 9 \\
\hline $2(\mathrm{CH})$ & 68.46 & $3.82(\mathrm{bs})$ & \\
\hline $3(\mathrm{CH})$ & 71.21 & 3.51 (bs) & \\
\hline $4(\mathrm{CH})$ & 42.80 & $1.46(\mathrm{~m})$ & 3,24 \\
\hline $5(\mathrm{C})$ & 49.00 & & \\
\hline $6\left(\mathrm{CH}_{2}\right)$ & 37.21 & $0.84(\mathrm{~m}), 2.45(\mathrm{~m})$ & 8 \\
\hline $7\left(\mathrm{CH}_{2}\right)$ & 19.01 & $1.46(\mathrm{~m})$ & 8 \\
\hline $8(\mathrm{CH})$ & 49.22 & $1.42(\mathrm{~m})$ & 7,25 \\
\hline $9(\mathrm{C})$ & 44.00 & & \\
\hline $10(\mathrm{CH})$ & 50.01 & $1.73(\mathrm{dd}, J 13,3)$ & 24 \\
\hline $11\left(\mathrm{CH}_{2}\right)$ & 33.80 & $1.31(\mathrm{~m})$ & 25 \\
\hline $12\left(\mathrm{CH}_{2}\right)$ & 28.85 & $1.53(\mathrm{~m}), 2.06(\mathrm{~m})$ & 14 \\
\hline $13(\mathrm{C})$ & 39.62 & & \\
\hline $14(\mathrm{C})$ & 38.78 & & \\
\hline $15\left(\mathrm{CH}_{2}\right)$ & 27.76 & $1.30(\mathrm{~m})$ & 26 \\
\hline $16\left(\mathrm{CH}_{2}\right)$ & 28.90 & $1.53(\mathrm{~m}), 2.06(\mathrm{~m})$ & 22 \\
\hline $17(\mathrm{C})$ & 36.40 & & \\
\hline $18(\mathrm{CH})$ & 45.00 & $1.64(\mathrm{~m})$ & $16,19,20,22,28$ \\
\hline $19\left(\mathrm{CH}_{2}\right)$ & 30.91 & $1.51(\mathrm{~m}), 2.15(\mathrm{~m})$ & 18,21 \\
\hline $20(\mathrm{CH})$ & 40.81 & $2.70(\mathrm{~m})$ & \\
\hline $21(\mathrm{C})$ & 213.22 & & \\
\hline $22(\mathrm{CH})$ & 76.73 & $4.41(\mathrm{~d}, J 5)$ & 28 \\
\hline $23\left(\mathrm{CH}_{3}\right)$ & 11.35 & $0.79(\mathrm{~d}, J 7)$ & 3 \\
\hline $24(\mathrm{C})$ & 176.48 & & \\
\hline $25\left(\mathrm{CH}_{3}\right)$ & 15.16 & $0.84(\mathrm{~s})$ & \\
\hline $26\left(\mathrm{CH}_{3}\right)$ & 17.27 & $0.80(\mathrm{~s})$ & 13,15 \\
\hline $27\left(\mathrm{CH}_{3}\right)$ & 18.65 & $1.27(\mathrm{~s})$ & $12,13,18$ \\
\hline $28\left(\mathrm{CH}_{3}\right)$ & 25.50 & $0.74(\mathrm{~s})$ & $16,17,18,22$ \\
\hline $30\left(\mathrm{CH}_{3}\right)$ & 14.92 & $0.90(\mathrm{~d}, J 6)$ & $19,20,21$ \\
\hline $\mathrm{OH}-2$ & - & $4.08(\mathrm{~m})$ & \\
\hline $\mathrm{OH}-3$ & - & $4.04(\mathrm{~d}, J 6)$ & \\
\hline $\mathrm{OH}-22$ & - & $4.46(\mathrm{~d}, J 5)$ & \\
\hline
\end{tabular}

a Splitting patterns are reported as singlet (s), broad signal (bs), doublet (d), double doublet (dd) and multiplet (m). HMBC: heteronuclear multiple bond correlation.

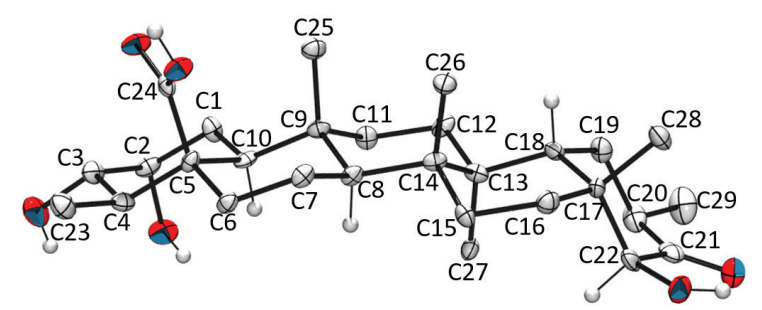

Figure 3. X-ray crystal structure of 2 . Some hydrogen atoms were omitted for better 3D visualization. hypothetical pathway for caryopristimerin biosynthesis was proposed. This dimer represents the first example of a homo Diels-Alder adduct of sesquiterpene and triterpene moieties. Compound 2 presents a 29-nor-friedelane skeleton bearing an unusual C-5 oxidized to a carboxyl, a position commonly substituted by a methyl group.

\section{Supplementary Information}

Crystallographic data (excluding structure factors) for the structures in this work were deposited in the Cambridge Crystallographic Data Centre as supplementary publication numbers CCDC 1537350 and (1) CCDC 1537351 (2). Copies of the data can be obtained, free of charge, via www.ccdc.cam.ac.uk/conts/retrieving.html or from the Cambridge Crystallographic Data Centre, CCDC, 12 Union Road, Cambridge CB2 1EZ, UK; fax: +44 1223336033. E-mail: deposit@ccdc.cam.ac.uk.

Supplementary data (MS, IR and NMR spectra of compounds 1-6 and LC/ESI-QTOF/MS analyses of the extract obtained through maceration) are available free of charge at http://jbcs.sbq.org.br as PDF file.

\section{Acknowledgments}

The authors are thankful to Conselho Nacional de Desenvolvimento Científico e Tecnológico (CNPq), Fundação Coordenação de Aperfeiçoamento de Pessoal de Nível Superior (CAPES) and Fundação de Amparo à Pesquisa do Estado de Minas Gerais (FAPEMIG) for the financial support, and MSc Salomão B. V. Rodrigues (UFMG) for the English revision and critical reading of the manuscript.

\section{References}

1. Paarakh, P. M.; Patil, L. J.; Thanga, S. A.; J. Nat. Rem. 2008, $8,116$.

2. Akaki, J.; Morikawa, T.; Miyake, S.; Ninomiya, K.; Okada, M.; Tanabe, G.; Pongpiriyadacha, Y.; Yoshikawa, M.; Muraoka, O.; Phytochem. Anal. 2014, 25, 544.

3. Vellosa, J. C. R.; Khalil, N. M.; Gutierres, V. O.; Santos, V. A. F. F. M.; Furlan, M.; Brunetti, I. L.; Oliveira, O. M. M. F. O.; Braz. J. Pharm. Sci. 2009, 45, 99.

4. Lião, L. M.; Caracelli, I.; Vieira, P. C.; Silva, M. F. G. F.; Fernandes, J. B.; Rodrigues-Filho, E.; Zukerman-Schpector, J.; An. Assoc. Bras. Quim. 1997, 46, 184.

5. Veitch, N. C.; Grayer, R. J.; Nat. Prod. Rep. 2011, 28, 1626.

6. Duarte, L. P.; Figueiredo, R. C.; de Sousa, G. F.; Soares, D. B. S.; Rodrigues, S. B. V.; Silva, F. C.; Silva, G. D. F.; Vieira-Filho, S. A.; Quim. Nova 2010, 33, 900. 
7. Somwong, P.; Suttisri, R.; Buakeaw, A; Fitoterapia 2011, 82, 1047.

8. Wang, Y.; Chen, W.-S.; Wu, Z.-J.; Xi, Z.-X.; Chen, W.; Zhao, G.-J.; Li, X.; Sun, L.-N.; Biochem. Syst. Ecol. 2011, 39, 205.

9. Carvalho, P. R. F.; Silva, D. H. S.; Bolzani, V. S.; Furlan, M.; Chem. Biodiversity 2005, 2, 367.

10. Brüning, R.; Hilderbert, W.; Phytochemistry 1978, 17, 1821.

11. Corsino, J.; de Carvalho, P. R. F.; Kato, M. J.; Latorre, L. R.; Oliveira, O. M. M. F.; Araújo, A. R.; Bolzani, V. D. S.; França, S. C.; Pereira, A. M. S.; Furlan, M.; Phytochemistry 2000, 55, 741.

12. Carneiro, C. C.; Silva, C. R.; Menezes, A. C. S.; Pérez, C. N.; Chen-Chen, L.; Genet. Mol. Res. 2013, 12, 2167.

13. Rodrigues, V. G.; Duarte, L. P.; Silva, R. R.; Silva, G. D. F.; Mercadante-Simões, M. O.; Takahashi, J. A.; Matildes, B. L. G.; Fonseca, T. H. S.; Gomes, M. A.; Vieira Filho, S. A.; Quim. Nova, 2015, 38, 237.

14. Gunatilaka, A. A. L. In Fortschritte der Chemie Organischer Naturstoffe/Progress in the Chemistry of Organic Natural Products, vol. 67; Herz, W.; Kirby, G. W.; Moore, R. E.; Steglich, W.; Tamm, C., eds.; Springer: Vienna, 1996, p. 1-123.

15. Mesa-Siverio, D.; Chávez, H.; Estévez-Braun, A.; Ravelo, A. G.; Tetrahedron 2005, 61, 429.

16. Rigaku Oxford Diffraction; CrysAlisPro Software System; Rigaku Corporation, Oxford, UK, 2016.

17. Sheldrick, G.; Acta Crystallogr., Sect. A: Found. Adv. 2015, 71, 3.

18. Altomare, A.; Cascarano, G.; Giacovazzo, C.; Guagliardi, A.; Burla, M. C.; Polidori, G.; Camalli, M.; J. Appl. Crystallogr. 1994, 27, 435 .
19. Macrae, C. F.; Edgington, P. R.; McCabe, P.; Pidcock, E.; Shields, G. P.; Taylor, R.; Towler, M.; van de Streek, J.; J. Appl. Crystallogr. 2006, 39, 453.

20. Ragasa, C. Y.; Ganzon, J.; Hofileña, J.; Tamboong, B.; Rideout, J. A.; Chem. Pharm. Bull. 2003, 51, 1208.

21. Estrada, R.; Cardenas, J.; Esquivel, B.; Rodriguez-Hahnn, L.; Phytochemistry 1994, 36, 747.

22. González, A. G.; Alvarenga, N. L.; Estévez-Braun, A.; Ravelo, A. G.; Bazzocchi, I. L.; Moujir, L.; Tetrahedron 1996, 52, 9597.

23. González, A. G.; Jiménez, J. S.; Moujir, L. M.; Ravelo, A. G.; Luis, J. G.; Bazzocchi, I. L.; Gutiérrez, A. M.; Tetrahedron 1992, 48, 769.

24. Kutney, J. P.; Hewitt, G. M.; Lee, G.; Piotrowka, K.; Roberts, M.; Retig, S. J.; Can. J. Chem. 1992, 70, 1455.

25. Nakano, K.; Oose, Y.; Oshiko, T.; Phytochemistry 1997, 46, 1179.

26. Rodrigues, V. G.; Duarte, L. P.; Silva, G. D. F.; Silva, F. C.; Góes, J. V.; Takahashi, J. A.; Pimenta, L. P. S.; Vieira Filho, S. A.; Quim. Nova 2012, 35, 1375.

27. Ezem, S. N.; Akpuaka, M. U.; Ajiwe, V. I. E.; Am. J. Chem. Appl. 2015, 2, 120.

28. Sotanaphun, U.; Suttisri, R.; Lipipun, V.; Bavovada, R.; Phytochemistry 1998, 49, 1749.

29. Drewes, S. E.; Selepe, M. A.; Van Heerden, F. R.; Archer, R. H.; Mitchell, D.; S. Afr. J. Bot. 2013, 88, 310.

Submitted: August 11, 2018

Published online: April 4, 2019 